\title{
RESEARCHPAPER
}

\section{Microbial population in soil as influenced by organic and inorganic fertilizers under different cropping systems}

\author{
N.R. MAIRAN AND A.S. DHAWAN \\ Department of Agricultural Chemistry and Soil Science, Marathwada Agricultural University, PARBHANI (M.S.) \\ INDIA
}

Article Info : Received : 07.06.2016; Revised : 16.08.2016; Accepted : 03.09 .2016

Studies were undertaken to evaluate the impact of application of organic and inorganic on soil microbial population under different cropping systems such as soybean-pigeonpea and sorghum-pigeonpea. After these two cycles, the soil microbial properties were significantly influenced due to various combinations of manurial treatments. The population of bacteria, fungi and actinomycetes decreased in higher proportion in control followed by farmer's practice, however, highest population of microbes was observed in the treatment receiving FYM. Fertilizer application alone showed relatively less increase in population of microbes. However, application of organics in the form of FYM, glyricidia, vermi-compost, plant and weed residues, biofertilizers, neem seed cake, press mud etc. helped to increase bacteria, actinomycetes, fungi and total microbes after these two cycles of cropping systems.

Key words : Organics, Inorganic, Soil biological components, Microbes

How to cite this paper : Mairan, N.R. and Dhawan, A.S. (2016). Microbial population in soil as influenced by organic and inorganic fertilizers under different cropping systems. Asian J. Bio. Sci., 11 (2) : 250-255.DOI : 10.15740/HAS/AJBS/11.2/250-255. 